\title{
Developing Student's Creative Thinking through Integrative Thematic Learning
}

\author{
Aan Hasanah ${ }^{1}$, Qiqi Yuliati Zaqiah², Yeti Heryati ${ }^{3}$ \\ UIN Sunan Gunung Djati Bandung, Indonesia \\ \{aan.hasanah@uinsgd.ac.id ${ }^{1}$, qqzaqiah67@gmail.com² ${ }^{2}$ yetiheryati_72@yahoo.com ${ }^{3}$ \}
}

\begin{abstract}
This research was initiated by the need to develop the ability to think creatively on the students of Islamic primary schools. The low creative thinking skills of students can be seen from various surveys conducted by some researchers. Even though the ability to think creatively is very important for students to face increasingly complex global competition. The earlier the age of students to develop their creative thinking skills, the better the results will be. Therefore this study is intended to find an effective learning model to develop students' creative thinking skills. This research is a Research and Development research. The research subjects were Islamic primary students in Bandung city. Research instruments in the form of tests, observations, and interviews, to measure four aspects of creative thinking were namely; fluency, flexibility, originality, and elaboration. The results showed that the thematic integrative learning model in Islamic elementary schools could develop both fluency and originality aspects, but still lacked the aspects of flexibility and elaboration. This is due to the strong influence of traditional rigid, normative learning models, doctrinal tendencies and strong teacher domination in the learning process.
\end{abstract}

Keywords: Creative thingking, integrative thematic learning.

\section{Introduction}

Creative thinking skills that are part of the level of human thinking are abilities that will help an individual to utilize one learning experience to another learning experience to solve problems [6]. This ability will direct someone not only to master basic skills such as understanding, predicting, and summarizing, but also to train them to become critical consumers in all contexts of the information they receive.

In fact, the ability to think creatively as a result of the learning process in schools has not shown satisfactory results. The IMSTEP-JICA Survey Team (1999) in the city of Bandung, among others, found a number of activities that were considered difficult by students to learn and by the teacher to teach them. These difficulties include proof of problem solving that requires mathematical reasoning, finding, generalization or conjecture, and finding the relationship between data or facts provided. Activities that are considered difficult are activities that require the ability to think creatively.

The results of other studies related to the fact of the low ability of creative thinking of elementary students is a form of evaluation which still on the cognitive aspects, rather than touching aspects of analysis. This can be seen from the types of worksheets used in general in 
the form of multiple choice questions. If this condition is allowed, students' ability to understand reading, critical thinking, and creative thinking will not develop [15].

Problem solving type, open questions or essays, and more challenging tasks are not found in the multiple choice model LKS. In fact, these types of questions are very challenging students' critical and creative thinking skills. In his article, Vito suggested teachers use performance tests to assess student achievement at the elementary school level. While teachers in primary schools are still accustom to use multiple choice model worksheets [16]. This can be seen from the questionnaire given to the teacher during the training in making worksheets in the Teacher Certification Training Program conducted by the Ministry of Religion. The findings of the survey, students found difficulties when faced with problem solving type that requires the ability to think creatively.

In the research report, Mayadiana wrote that the critical and creative thinking skills of elementary school teacher candidates were still low, which only reached $36.26 \%$ for students with a science background, $26.62 \%$ for students with a non- science background, and 34,06\% for all students [10]. It is related with the results of Maulana's study (2008: v) that the average value of critical thinking abilities of D2 PGSD students is less than $50 \%$ of the maximum score.

The importance of teaching and developing the ability to think creatively, especially for students of Islamic elementary schools must be seen as urgent, because students at the age of primary students are the golden period for planting and developing critical and creative thinking skills. The importance of this ability is essential to be mastered in modern life now days. Wilson in Muhfahroyin suggests several reasons about the need for critical thinking skills, namely [12]: (1) Knowledge based on memorization has been discredited, individuals will not be able to save knowledge in their memories for future use; (2) Information is widespread so rapidly that individuals need abilities that can be channelled so that they can identify various problems in different contexts at different times during their lives; (3) The complexity of modern work requires staffs who are able to demonstrate understanding and make decisions in the world of work; (4) Modern society needs individuals to combine information from various sources and make decisions. In other words, "workers who enter the workplace in the future must truly have various abilities that will make them systems thinkers and people who have never stopped learning throughout their lives [12]".

On the other hand, as stated by Chafe basically the practice of learning in classes has not led to teaching how to think [3]. The education system focuses more on delivering information than developing thinking skills [5]. In fact, information has not become knowledge until the human mind analyzes it, applies it, synthesizes it, evaluates it, and integrates it into life so that information can be used for productive purposes, namely making decisions and solving problems.

The development of effective learning models can be done in the learning process in the classroom. The learning process must be designed to be able to develop learning outcomes that lead to the optimization of students' creative thinking skills. Basically the development of creative thinking will be closely related to the improvement of the quality of educational output namely the formation of good character quality in students [8].

The aim of this research is to develop effective learning models and creative thinking skills of elementary school students. So that an integrated learning model was developed which integrates several social studies subjects ; social, cultural, language, arts, which overlap which is then formulated in one theme 'ASIA (An Incredible of Indonesia) 'which is discussed in full version. Referring to Susilowati's opinion (2010) that this integrated model has several 
advantages over other models; understanding the concept holistically, the theme is highly contextual, the implementation in the field is very efficient.

By using a thematic integrative learning model, the ability to think critically of Islamic primary students is measured through four components, as developed by Cotton as in the table below [4]:

Table 1. Creative Thinking Indicators

\begin{tabular}{ll}
\hline \multicolumn{1}{c}{ Aspects } & \multicolumn{1}{c}{ Description } \\
\hline Fluency (lots of ideas) & $\begin{array}{l}\text { 1. Generating lots of ideas, lots of answers, lots of problem } \\
\text { solving, lots of questions smoothly; } \\
\text { 2. Provide many ways or suggestions to do various things; } \\
\text { 3. Always think of more than one answer. }\end{array}$ \\
\hline $\begin{array}{l}\text { Flexibility (changing } \\
\text { perspective easily) }\end{array}$ & $\begin{array}{l}\text { 1. Produce a variety of ideas, answers, or questions, can see a } \\
\text { problem from different points of view; } \\
\text { 2. Look for many alternatives or different directions; } \\
\text { 3. Able to change the way of approach or way of thinking. }\end{array}$ \\
\hline $\begin{array}{l}\text { Originality (composing } \\
\text { something new) }\end{array}$ & $\begin{array}{l}\text { 1. Able to give birth to new and unique expressions; } \\
\text { 2. Think of unusual ways to express yourself; }\end{array}$ \\
\hline $\begin{array}{l}\text { Elaboration } \\
\text { (developing another }\end{array}$ & $\begin{array}{l}\text { 1. Able to make unusual combinations of parts or elements. } \\
\text { 2. Adding or detailing the details of an object, idea, or situation } \\
\text { idea of an idea) }\end{array}$ \\
\hline
\end{tabular}

Integrative thematic learning model is learning that combines several interconnected fields of study which are formulated in the form of themes and discussed together [9]. The thematic integrative learning process involves subjects, namely, Bahasa Indonesia, Civics, Arts and Social. Learning scenarios are designed with three stages, namely preliminary activities, core activities, and closing activities. In the preliminary stage, the teacher checks self-readiness by completing attendance sheets and checking the tidiness of clothing, position and seating according to learning activities. Furthermore, the teacher informs the theme that will be learned, namely "Keanekaragaman Budaya Bangsaku".

The core stage is accompanied by activities to observe, ask, collect and process data and communicate. The details of activities at the core stage are as follows; (1)In the observation phase, students observe cultural shows of differences in traditional clothing, traditional houses, traditional dances, special foods and traditional musical instruments. This activity stimulates students to enter the core material. (2)The questioning stage, students and teachers discuss the questions displayed. At this stage, there is an identification of problems and data problems that will be enrichment of learning. (3)The stage of collecting and processing data, students create mind maps of traditional clothing, traditional houses, traditional dances, special foods and traditional musical instruments. To see students' understanding of the core material, the teacher invites students to play games to distinguish traditional clothes, traditional houses, traditional dances, typical foods and traditional musical instruments. The data they get from the mind map or the results of the game, they become a poster and pop up. (4)The stage of communicating, the teacher asks students to display posters and pop ups, then visits work between groups and comments to each other. Learning closes with the activities of students together with the teacher concludes learning and reflects on what students get and feel during the learning process. The entire learning process is closed by singing again the regional songs of West Java. 


\section{Methods}

The development model is carried out through stages; pre-research, model design preparation, model feasibility testing, field testing, phase improvement of the model design, and final implementation of the model [14]. It is to see the application of the final model in the field. Analysis of the data used in this study is the score of students in the results of performance evaluation and project to measure the level of creative thinking of Islamic primary students with percentage calculations, as in the table below [7]:

Table 2. Assessment Rubrics

\begin{tabular}{|c|c|c|c|c|c|}
\hline Aspects & Description & $9-10$ & $7-8,9$ & $6-6,9$ & Notes \\
\hline $\begin{array}{l}\text { Fluency (lots of } \\
\text { ideas) }\end{array}$ & $\begin{array}{l}\text { 1. Generating lots } \\
\text { of ideas, lots of } \\
\text { answers, lots of } \\
\text { problem } \\
\text { solving, lots of } \\
\text { questions } \\
\text { smoothly; } \\
\text { 2. Provide many } \\
\text { ways or } \\
\text { suggestions to } \\
\text { do various } \\
\text { things; } \\
\text { 3. Always think of } \\
\text { more than one } \\
\text { answer. }\end{array}$ & $\begin{array}{l}\text { - Complete and } \\
\text { informative } \\
\text { mind map } \\
\text { containing more } \\
\text { than } 5 \text { ideas, } \\
\text { - there are } \\
\text { pictures / } \\
\text { symbols, } \\
\text { - contains } \\
\text { information } \\
\text { that provides } \\
\text { information on } \\
\text { more than two } \\
\text { of each idea }\end{array}$ & $\begin{array}{ll}- & \begin{array}{l}\text { Mind map } \\
\text { clear and }\end{array} \\
\text { contains } 5 \\
\text { ideas, } \\
\text { There is } \\
\text { symbol/pictu } \\
\text { re } \\
\text { Give } 2 \text { clear } \\
\text { information } \\
\text { each idea }\end{array}$ & $\begin{array}{l}\text { - Complete and } \\
\text { informative } \\
\text { mind map } \\
\text { containing } 4 \\
\text { or less than } 4 \\
\text { ideas, } \\
\text { - There are no } \\
\text { images / } \\
\text { symbols, } \\
\text { - contains 1 } \\
\text { information } \\
\text { from each } \\
\text { idea }\end{array}$ & $\begin{array}{l}\text { Taken from } \\
\text { mind map }\end{array}$ \\
\hline $\begin{array}{l}\text { Flexibility } \\
\text { (changing } \\
\text { perspective } \\
\text { easily) }\end{array}$ & $\begin{array}{l}\text { 1. Produce a } \\
\text { variety of ideas, } \\
\text { answers, or } \\
\text { questions, can } \\
\text { see a problem } \\
\text { from different } \\
\text { points of view; } \\
\text { 2. Look for many } \\
\text { alternatives or } \\
\text { different } \\
\text { directions; } \\
\text { 3. Able to change } \\
\text { the way of } \\
\text { approach or } \\
\text { way of } \\
\text { thinking. }\end{array}$ & $\begin{array}{l}\text { Able to pair } 5 \\
\text { concepts } \\
\text { correctly }\end{array}$ & $\begin{array}{l}\text { Being able to } \\
\text { pair } 4 \text { pieces of } \\
\text { the concept } \\
\text { correctly }\end{array}$ & $\begin{array}{l}\text { Able to pair } 3 \text { or } \\
\text { less of } 3 \\
\text { concepts } \\
\text { correctly }\end{array}$ & $\begin{array}{l}\text { Taken from spy } \\
\text { games }\end{array}$ \\
\hline $\begin{array}{l}\text { Originality } \\
\text { (composing } \\
\text { something } \\
\text { new) }\end{array}$ & $\begin{array}{l}\text { 1. Able to give } \\
\text { birth to new } \\
\text { and unique } \\
\text { expressions; } \\
\text { 2. Think of } \\
\text { unusual ways to } \\
\text { express } \\
\text { yourself; } \\
\text { 3. Able to make } \\
\text { unusual } \\
\text { combinations of } \\
\text { parts or } \\
\text { elements. }\end{array}$ & $\begin{array}{l}\text { The layout of } \\
\text { the poster is } \\
\text { interesting, neat } \\
\text { and there is an } \\
\text { explanation } \\
\text { using the } \\
\text { language itself }\end{array}$ & $\begin{array}{l}\text { The poster } \\
\text { layout is less } \\
\text { attractive, less } \\
\text { neat, there is an } \\
\text { explanation but } \\
\text { copying from } \\
\text { the material } \\
\text { provided. }\end{array}$ & $\begin{array}{l}\text { The poster } \\
\text { layout is not } \\
\text { attractive, not } \\
\text { neat, and there } \\
\text { is no } \\
\text { explanation. }\end{array}$ & $\begin{array}{l}\text { Taken from } \\
\text { poster }\end{array}$ \\
\hline $\begin{array}{l}\text { Elaboration } \\
\text { (developing }\end{array}$ & $\begin{array}{l}\text { 1. Able to enrich } \\
\text { and develop an }\end{array}$ & $\begin{array}{l}\text { Add } 5 \\
\text { information on }\end{array}$ & $\begin{array}{l}\text { Add 3-4 } \\
\text { information on }\end{array}$ & $\begin{array}{l}\text { Add 1-2 } \\
\text { information on }\end{array}$ & $\begin{array}{l}\text { Taken from pop } \\
\text { up and poster }\end{array}$ \\
\hline
\end{tabular}




\begin{tabular}{|c|c|c|c|c|}
\hline $\begin{array}{l}\text { another idea of } \\
\text { an idea) }\end{array}$ & $\begin{array}{l}\text { idea or product; } \\
\text { 2. Adding or } \\
\text { detailing the } \\
\text { details of an } \\
\text { object, idea, or } \\
\text { situation so that } \\
\text { it becomes } \\
\text { more } \\
\text { interesting. }\end{array}$ & $\begin{array}{l}\text { the poster } \\
\text { related to the } \\
\text { province that } \\
\text { was created } \\
\text { Add } 5 \\
\text { ornaments to } \\
\text { the pop up } \\
\text { outside of the } \\
\text { image provided }\end{array}$ & $\begin{array}{l}\text { posters related } \\
\text { to the province } \\
\text { created } \\
\text { Add } 3-4 \\
\text { ornaments to } \\
\text { the pop up } \\
\text { outside of the } \\
\text { image provided }\end{array}$ & $\begin{array}{l}\text { posters related } \\
\text { to the province } \\
\text { created } \\
\text { Add } 1-2 \\
\text { ornaments to } \\
\text { the pop up } \\
\text { outside of the } \\
\text { image provided }\end{array}$ \\
\hline
\end{tabular}

The assessment rubric is intended to provide a score of student achievement in each aspect of creative thinking. Furthermore, this grouping is qualitatively weighted in each aspect as in the table below:

Table 3. Creative Thinking Assessment Criteria

\begin{tabular}{lcc}
\hline No. & Level of Achievement & Category \\
\hline 1. & $9-10$ & High \\
\hline 2. & $7-8,9$ & Medium \\
\hline 3. & $6-6,9$ & Low \\
\hline
\end{tabular}

\section{Result and Discussion}

The results of this study indicate that the student group of Islamic elementary schools show varied results in every aspect of creative thinking. Data analyses based on indicators of creative skills referring to the opinion of Alvino cited in Cotton, namely fluency, flexibility, originality, and elaboration [4].

\subsection{Fluency aspects}

The fluency aspect of creative thinking skills refers to the aspects of: a) sparking many ideas, many answers, many problem solving, many questions smoothly; b) provide many ways or suggestions to do various things; c) always think of more than one answer. In the fluency aspect, MI student groups show: $50.5 \%$ are in the high category; $36 \%$ medium category and $13.5 \%$ low category [2]. Through innovative and recreational learning, most students can achieve high grades, because students are given the freedom to express many ideas, ideas and questions.

\subsection{Flexibility aspects}

Flexibility creative thinking skills refer to aspects: a) able to form a coherent conceptual relationship; b) Produce various ideas, answers, or questions, can see a problem from different points of view; c) look for many different alternatives or directions. In this aspect MI student groups show results: $30 \%$ of students are in the high category; $57 \%$ are in the medium category; and $13 \%$ are in the low category. In the aspect of flexibility, most students are only in the medium category. This is because students are still limited with alternative answers.

\subsection{Originality aspects}

The originality aspect refers to: a) able to produce new and unique expressions; b) think of unusual ways to express themselves. In this aspect MI student groups show the following results: $40 \%$ are in the high category; $48.5 \%$ are in the medium category; and $11.5 \%$ are in the 
low category. In this aspect most students have many new expressions in expressing the ideas requested by the teacher.

\subsection{Elaboration aspects}

Elaboration aspects of creative thinking skills refer to aspects: a) able to enrich and develop an idea or product; b) adding or detailing the details of an object, idea, or situation so that it becomes more interesting. Elaboration aspects of creative thinking skills refer to aspects: a) able to enrich and develop an idea or product; b) adding or detailing the details of an object, idea, or situation so that it becomes more interesting. In this aspect MI student groups show results: $0 \%$ in the high category; $78 \%$ are in the moderate category and $22 \%$ are in the low category. What's interesting in the aspect of Elaboration, which is the highest aspect in creative thinking skills where students are asked to explain things in detail and in different ways. In this category none of the students achieved high grades. Most students are in the moderate category, and the rest are in the low category. The ability to elaborate ideas is still lacking, and students seem hesitant to give the correct answers in different ways than those taught by the teacher.

From the results of the above analysis shows that Islamic primary students have great potential to be developed optimally for creative thinking. The strength of Islamic primary students in the fluency aspect is quite high where many students give questions and provide many answers and produce diverse products. But in the aspect of flexibility the majority of students are only in the moderate category, this is suspected as a result of the dominance of the teacher in learning is still very strong, learning approaches that are still rigid, normative and tend to be doctrinaire, so the ability of students to see things from a perspective different is still weak. What is interesting in the originality aspect of Islamic primary students is quite good in expressing problems with current terms (update) meaning that Islamic primary students are the same as students in other schools in responding to problems that develop in the present way. Another thing that needs teacher's attention is the elaboration aspect, where the indicator can elaborate the idea, can correct it in a detailed form, and provide answers in a different way (out of the box). In this aspect, there are no Islamic primary students who show elaboration skills in high categories. Most of them are only in the medium category, and the rest still have low skills. Even though the level of elaboration is important to develop students' thinking creativity. This is due to a learning system that does not provide ample room for the development of this aspect. This is possible also related to the competence of the teacher.

The findings in this study support what has been said in previous studies. Creative thinking skills can improve well in an atmosphere of learning that is orderly and fun, relaxing students are not burdened and given the opportunity to evaluate their own results at home[11]. The same thing was also conveyed by Rofi'udin found that learning activities that provide freedom to students in determining the topics / problems discussed related to the material being studied, propose ideas in an atmosphere of mutual respect and mutual acceptance can encourage students to think creatively and divergently, and do exploration, all of this can train students' creative thinking skills [13]. Meanwhile, in his research, Aryana found that students who were given innovative learning models had creative thinking skills than students who were given traditional learning models [1].

\section{Conclusion}

Thematic Integrative Learning Model influences and significantly effectively can improve students' creative thinking skills in fluency and originality aspects. But it is still not optimal 
for aspects of flexibility and elaboration. In other words, the implementation of thematic integrative learning can effectively improve students' creative thinking skills, if the supporting prerequisites are met. Supporting preconditions needed include: the ability of teachers to implement and integrate innovative learning models, adequate infrastructure and a conducive learning environment. Students' creative thinking skills will grow if the learning done encourages students to be active as subjects of learning.

\section{Acknowledgement}

Research Center of LP2M Universitas Islam Negeri Sunan Gunung Djati Bandung. BOPTN UIN Sunan Gunung Djati Bandung.

\section{References}

[1] Arnyana, I. B. P. Pengaruh Penerapan Strategi Pembelajaran Inovatif pada Pelajaran Biologi Terhadap Kemampuan Berpikir Kreatif Siswa, Jurnal pendidikan dan pengajaran IKIP negeri Singaraja no 3 (2006)

[2] Angelo, B.J.D. Using Source Analysis to Promote Critical Thingking, Research Strategies, Vol 18, 303-309. (2001)

[3] Chafe, Signs of the Times: Unlocking the Symbolic Language of World Events, 1999

[4] Cotton, Macmillan Physical Science Series: Lanthanides and Actinides. Macmillan Education. London (1991)

[5] Dimyati dan Mudjiono. Belajar dan Pembelajaran, Jakarta :Rineka Cipta (2006)

Dwi Murwani, Elika, Peran Guru dalam Membangun Kesadaran Kritis Siswa, hal 59-6, Jurnal Pendidikan Penabur No.06/Th.V/Juni (2006)

[6] Ennis H, Robert, Critical Thinking. New Jersey: Prentice Hall (1996)

[7] Fraenkel, J. R \& Wallen, N. E. How to Design and Evaluate Research. New York: McGraw-Hill Inc. (1993)

[8] Hasanah, A., Gustini, N., \& Rohaniawati, D. Cultivating Character. Education Based on Sundanese Culture Local wisdom. Jurnal Pendidikan Islam, 2 (2), 231-253. doi:http://dx.doi.org/10.15575/jpi.v2i2.788. (2016)

[9] Isjoni, Pendekatan Integrated Learning, Bandung, Falah Production, (2007)

[10] Joyce Bruce \& Marsha Weil, by James M. Wolf. (2000). Models of Teaching, USA: A Person Education Company

Mayadiana, D. Pembelajaran dengan pendekatan Diskursif untuk meningkatkan kemampuan berpikir kritis matematik mahasiswa calon guru Sekolah dasar, Tesispada SPS UPI, tidak diterbitkan (2005)

[11] Marwiyah Siti, Karakterisasi dan Respon Pemangkasan Tunas Air terhadap Produksi serta Kualitas Buah Genotipe

Tomat Lokal. DOI: 10.29244/jhi.5.2.73-83 (2015)

[12] Muhfahroyin, Pengaruh Strategi Pembelajaran Integrasi STAD dan TPS dan Kemampuan Akademik terhadap Hasil Belajar Kognitif Biologi, Kemampuan Berpikir Kritis, dan Keterampilan Proses Siswa SMA di Kota Metro. Program Pascasarjana: Universitas Negeri Malang. Disertasi, Tidak Diterbitkan pp. 3 (2009)

[13] Rofi'udin, Pedoman Penulisan Karya Ilmiah. UM.Press. Malang (2000)

[14] Sugiyono, Metode penelitian Kuantitatif Kualitatif dan R\&D, Penerbit Alfabeta. 2010

[15] Sutrisno, www.erlangga.co.id

[16] Vito, Differences in Creative Thinking between Japanese and American Fifth Grade Children, Ibaraki University Faculty of

Education Bulletin, No.40 p53-59 1991 